\title{
$\angle$ Research Square \\ Development of Highly Validated SNP Markers for Genetics Analyses of Chestnut Species.
}

Clement LARUE ( $\square$ clement.larue@inrae.fr)

BIOGECO: Biodiversite Genes et Communautes https://orcid.org/0000-0003-2931-345X

\section{Erwan Guichoux}

BIOGECO: Biodiversite Genes et Communautes

\section{Benoît Laurent}

BIOGECO: Biodiversite Genes et Communautes

\section{Teresa Barreneche}

BFP

\section{Cécile Robin}

BIOGECO: Biodiversite Genes et Communautes

\section{Marie Massot}

BIOGECO: Biodiversite Genes et Communautes

\section{Adline Delcamp \\ BIOGECO: Biodiversite Genes et Communautes \\ Rémy J. Petit \\ BIOGECO: Biodiversite Genes et Communautes}

\section{Research Article}

Keywords: Genetics Analyses, Chestnut Species, polymorphism

Posted Date: June 7th, 2021

DOI: https://doi.org/10.21203/rs.3.rs-314998/v1

License: (c) (i) This work is licensed under a Creative Commons Attribution 4.0 International License. Read Full License 


\section{Abstract}

To better study and manage chestnut trees and species, we identified nuclear single nucleotide polymorphism (SNP) markers using restriction-associated DNA sequencing. Out of 343 loci tested, 68 SNP markers were selected that withhold stringent quality criteria such as quasi-systematic amplification across species and Mendelian segregation in both purebred and hybrid individuals. They provide sufficient power for species, hybrids and backcross characterization as well as for clonal identification, as shown by a comparison with single sequenced repeat (SSR) loci.

\section{Introduction}

Chestnuts are self-incompatible and insect-pollinated Fagaceae trees from the Northern hemisphere (Stout 1926; Xiong et al. 2019; Barreneche et al. 2019; Larue et al. 2021a, b). Three species are widely cultivated for their nutritious nuts, the Japanese (Castanea crenata), Chinese (C. mollissima) and European ( $C$. sativa) chestnuts (Barreneche et al. 2019). C. sativa is very vulnerable to ink disease and chestnut blight caused by pathogenic agents originating from Asia (Gonthier and Robin 2019). Hybrids between Asiatic species and C. sativa proved resistant to ink disease and were selected for cultivation in Europe. Genetic markers could help differentiate chestnut species, hybrids and other introgressed material as well as varieties, thereby facilitating the management of orchards. Such markers could also clarify the status of natural chestnut stands threatened by the propagation of diseases and by genetic pollution. A number of molecular markers have been previously developed in chestnuts, especially SSRs (e.g. Buck et al. 2003; Marinoni et al. 2003; Durand et al. 2010; Fernández-Cruz and Fernández-López 2012; PereiraLorenzo et al. 2017; Bouffartigue et al. 2020; Laurent et al. 2020; Nishio et al. 2021). However, SNPs have some important advantages over SSRs (Guichoux et al. 2011). First, genotyping errors are much rarer with SNPs than with SSRs, facilitating standardisation across laboratories. Second, SNP genotyping platforms make it possible to quickly characterize and score a large number of samples at reduced costs. Although SNPs have already been developed in chestnuts (Santos et al. 2017; Nishio et al. 2018; Nunziata et al. 2020; Sun et al. 2020), no SNP assays have been designed and optimized for the mentioned applications.

We identified SNPs in the nuclear genome of chestnuts using restriction-site associated DNA sequencing (Miller et al. 2007). We used three samples from the INRAE chestnut germplasm collection, one $C$. mollissima (Ca 737), one $C$. crenata (Ca 04) and one $C$. sativa (Ca 577). We also included SNPs originating from C. mollissima CCall_Unigene_V2 assembly data and from C. dentata AC454_Unigene_V3 contig data (Santos et al. 2017; http://www.hardwoodgenomics.org/).

We first tested the markers on a set of 95 samples including the three sequenced parents, the descendants of two interspecific crosses (Ca 577 x Ca 737 and $\mathrm{Ca} 577$ x Ca 04) and nine French cultivars. Their DNA was isolated from leaves dried in silica gel with Qiagen DNeasy 96 Plant kit. We further checked the markers on another set of 95 unique genotypes from the INRAE chestnut germplasm collection, which includes the three chestnut species and several F1, F2 and advanced hybrids. Their DNA was isolated from frozen leaves with a CTAB DNA isolation protocol (Supplementary 1) adapted from Doyle and Doyle (1987).

We selected 343 candidate SNPs, 37 loci from Santos et al. (2017) and 306 loci originating from a restrictionassociated DNA sequencing experiment (García et al. 2018) and. These loci were successfully sequenced in all three parents, were heterozygous in at least one of them, and lacked variation within at least 50 bp around the SNP position. We designed nine MassARRAY multiplexes (Assay Design Suite v2.0, Agena Bioscience, San Diego, USA) of up to 40 loci. Data analysis relied on MassARRAY Typer Analyzer 4.0.26.75 (Agena Biosciences). We excluded all 
monomorphic SNPs, loci with weak or ambiguous signal (i.e., displaying more than three genotypes clusters or with unclear cluster delimitation) and loci with $>10 \%$ missing data. Out of the 343 loci tested, 237 were validated (Larue 2021, File 1).

We combined the best markers in two new multiplexes of 40 and 39 loci (Larue 2021, File 2) and used them to genotype the second set of 95 individuals. All 79 loci were polymorphic. Extensive testing with Mismatchfinder (https://github.com/jschoete/mismatchfinder, Supplementary 2) of over 3000 progeny identified 68 markers segregating according to Mendelian expectations that worked well on all species. The mean amplification rate was 99.9\% (97.8-100\%) per SNP locus and 99.9\% (98.7-100\%) per sample. By contrast, the mean amplification rate was 92.2\% (76.9-100\%) per SSR locus and 91.7\% (41.5-100\%) per sample (Laurent et al. 2020).

These markers are listed in Table 1, and 66 of the 68 SNPs are located on the chromosome assembly of $C$. mollissima genome (Sun et al. 2020). Table 1 also includes allelic frequencies for the three chestnut species and for C. sativa x C. crenata hybrids, computed using Genalex 6.51 (Peakall and Smouse 2012).

To evaluate the utility of these markers for species and hybrid identification, we used the Bayesian clustering analysis software Structure (Pritchard et al. 2000) and compared the results with those obtained with SSRs (Laurent et al. 2020). A total of 91 unique genotypes were characterized with both types of markers and used for the comparison (Larue 2021, Files 3 and 4; Supplementary 3). Three clear-cut genetic clusters were identified with both markers, matching well with the known identity of the trees, confirming the taxonomic utility of these SNPs (Figure 1). We also computed the probability of identity for the 68 SNPs and the 94 SSRs (Supplementary 4). For the SNPs, they were all close to zero, showing that all chestnut genotypes can be easily differentiated with these markers. To conclude, the developed SNPs are suitable for identification of chestnut cultivars, species and hybrids. They should help manage production orchards and monitor the remaining wild chestnut stands.

\section{Declarations}

\section{Funding}

This paper is part of the PhD of CL. The work was supported by ANRt funding under CIFRE PhD program to CL. Financial support to Invenio for this project was provided by the Conseil Régional d'Aquitaine for CL PhD work, as part of the REGINA project, and for BL work (Grant Number 2018-1R20204 project DIGIE "chestnut dieback: vulnerability and genetic determinism of ink disease resistance"). SNP development and genotyping were performed at the Genome Transcriptome Facility of Bordeaux (grants from the Conseil Régional d'Aquitaine no. 20030304002FA and 20040305003FA, from the European Union FEDER no. 2003227 and from Investissements d'Avenir ANR-10-EQPX-16-01).

\section{Compliance with Ethical Standards}

\section{Competing Interests}

All authors certify that they have no affiliations with or involvement in any organization or entity with any financial interest or non-financial interest in the subject matter or materials discussed in this manuscript.

\section{Animal Research}

This technical note does not contain any studies with animals performed by any of the authors. 
Consent to Participate

This work does not contain any studies with human participants performed by any of the authors.

Consent to Publish

This work does not contain any studies with human participants performed by any of the authors.

\section{Author contribution (CRediT taxonomy)}

Clément Larue: Conceptualization, Investigation, Resources, Formal analysis, Writing - original draft

Erwan Guichoux: Conceptualization, Methodology, Formal analysis, Writing - review \& editing

Benoît Laurent: Formal analysis, Writing - review \& editing

Teresa Barreneche: Conceptualization, Funding acquisition, Writing - review \& editing

Cécile Robin: Conceptualization, Funding acquisition, Writing - review \& editing

Marie Massot: Investigation, Resources, Writing - review \& editing

Adline Delcamp: Investigation, Resources, Writing - review \& editing

Rémy J. Petit: Conceptualization, Funding acquisition, Supervision, Writing - review \& editing

\section{Data Availability}

All data are available on Data INRAE:

Larue C (2021) Development of SNP markers for the identification of chestnut species, hybrids and varieties. https://doi.org/10.15454/XEMDLD

\section{Acknowledgments}

We thank J. Schoeters for developing MISMATCHFINDER software, C. Lalanne for DNA isolation protocol development and L. Dubois, C. Boury and C. Mouden for SNP identification and genotyping. We thank INRAE experimental unit Vigne Bordeaux (UEVB) in Villenave d'Ornon, and INRAE experimental unit Forêt Pierroton (UEFP) for their continuous support for chestnut orchards management.

\section{References}

Barreneche T, Botta R, Robin C (2019) Advances in breeding of chestnuts. In: Achieving sustainable cultivation of tree nuts, Burleigh Dodds Science Publishing Limited, Cambridge (UK). Burleigh Dodds Science Publishing, pp 317348

Bouffartigue C, Debille S, Fabreguettes O, et al (2020) Two main genetic clusters with high admixture between forest and cultivated chestnut (Castanea sativa Mill.) in France. Ann For Sci 77:74. https://doi.org/10.1007/s13595-02000982-w 
Buck EJ, Hadonou M, James CJ, et al (2003) Isolation and characterization of polymorphic microsatellites in European chestnut (Castanea sativa Mill.). Mol Ecol Notes 3:239-241. https://doi.org/10.1046/j.14718286.2003.00410.x

Doyle JJ, Doyle JL (1987) A rapid DNA isolation procedure for small quantities of fresh leaf tissue. Phytochem Bull 19:11-15

Durand J, Bodénès C, Chancerel E, et al (2010) A fast and cost-effective approach to develop and map EST-SSR markers: oak as a case study. BMC Genomics 11:570. https://doi.org/10.1186/1471-2164-11-570

Fernández-Cruz J, Fernández-López J (2012) Morphological, molecular and statistical tools to identify Castanea species and their hybrids. Conserv Genet 13:1589-1600. https://doi.org/10.1007/s10592-012-0408-0

García C, Guichoux E, Hampe A (2018) A comparative analysis between SNPs and SSRs to investigate genetic variation in a juniper species (Juniperus phoenicea ssp. turbinata). Tree Genet Genomes 14:87.

https://doi.org/10.1007/s11295-018-1301-x

Gonthier P, Robin C (2019) Diseases. In: The chestnut handbook: crop and forest management. CRC Press

Guichoux E, Lagache L, Wagner S, et al (2011) Current trends in microsatellite genotyping. Mol Ecol Resour 11:591611. https://doi.org/10.1111/j.1755-0998.2011.03014.x

Larue C (2021) Development of SNP markers for the identification of chestnut species, hybrids and varieties. https://doi.org/10.15454/XEMDLD

Larue C, Austruy E, Basset G, Petit RJ (2021a) Revisiting pollination mode in chestnut (Castanea spp.): an integrated approach. Bot Lett 0:1-25. https://doi.org/10.1080/23818107.2021.1872041

Larue C, Barreneche T, Petit RJ (2021b) Efficient monitoring of phenology in chestnuts. Sci Hortic 281:109958. https://doi.org/10.1016/j.scienta.2021.109958

Laurent B, Larue C, Chancerel E, et al (2020) Microhaplotype genotyping-by-sequencing of 98 highly polymorphic markers in three chestnut tree species. Conservation Genet Resour. https://doi.org/10.1007/s12686-020-01157-5

Marinoni D, Akkak A, Bounous G, et al (2003) Development and characterization of microsatellite markers in Castanea sativa (Mill.). Mol Breed 11:127-136. https://doi.org/10.1023/A:1022456013692

Miller MR, Dunham JP, Amores A, et al (2007) Rapid and cost-effective polymorphism identification and genotyping using restriction site associated DNA (RAD) markers. Genome Res 17:240-248. https://doi.org/10.1101/gr.5681207

Nishio S, Takada N, Terakami S, et al (2021) Genetic structure analysis of cultivated and wild chestnut populations reveals gene flow from cultivars to natural stands. Sci Rep 11:240. https://doi.org/10.1038/s41598-020-80696-1

Nishio S, Takada N, Terakami S, et al (2019) Estimation of effective pollen dispersal distance for cross-pollination in chestnut orchards by microsatellite-based paternity analyses. Sci Hortic 250:89-93.

https://doi.org/10.1016/j.scienta.2019.02.037

Nunziata A, Ruggieri V, Petriccione M, De Masi L (2020) Single Nucleotide Polymorphisms as practical molecular tools to support European chestnut agrobiodiversity management. Int J Mol Sci 21:4805.

Page 5/9 
https://doi.org/10.3390/ijms21134805

Peakall R, Smouse PE (2012) GenAlEx 6.5: genetic analysis in Excel. Population genetic software for teaching and research--an update. Bioinformatics 28:2537-2539. https://doi.org/10.1093/bioinformatics/bts460

Pereira-Lorenzo S, Ramos-Cabrer AM, Barreneche T, et al (2017) Database of European chestnut cultivars and definition of a core collection using simple sequence repeats. Tree Genet Genomes 13:114.

https://doi.org/10.1007/s11295-017-1197-x

Pritchard JK, Stephens M, Donnelly P (2000) Inference of population structure using multilocus genotype data.

Genetics 155:945-959

Santos C, Nelson CD, Zhebentyayeva T, et al (2017) First interspecific genetic linkage map for Castanea sativa $\mathrm{x}$ Castanea crenata revealed QTLs for resistance to Phytophthora cinnamomi. PLOS ONE 12:e0184381.

https://doi.org/10.1371/journal.pone.0184381

Stout AB (1926) Why are chestnuts self-fruitless? Jour N Y Bot Gard 27:154-158

Sun Y, Lu Z, Zhu X, Ma H (2020) Genomic basis of homoploid hybrid speciation within chestnut trees. Nat Commun 11:3375. https://doi.org/10.1038/s41467-020-17111-w

Xiong H, Zou F, Guo S, et al (2019) Self-sterility may be due to prezygotic late-acting self-incompatibility and earlyacting inbreeding depression in Chinese chestnut. J Am Soc Hortic Sci 144:172-181.

https://doi.org/10.21273/JASHS04634-18

\section{Tables}

Table 1: Information about the 79 SNPs. 


\begin{tabular}{|c|c|c|c|c|c|c|c|}
\hline Name & Chromosome $^{1}$ & Position & Alleles ${ }^{2}$ & crenata & mollissima & sativa & $s \times c$ \\
\hline 10090_56 & 03 & 66.9 & $\mathrm{~A} / \mathrm{G}$ & 0.714 & 0.235 & 0.863 & 0.500 \\
\hline 10271_144 & 02 & 66.6 & $\mathrm{~A} / \mathrm{G}$ & 1.000 & 1.000 & 0.325 & 0.735 \\
\hline 1156_97 & 08 & 19.8 & $\mathrm{G} / \mathrm{A}$ & 1.000 & 1.000 & 0.438 & 0.676 \\
\hline 11811_126 & 03 & 51.0 & $\mathrm{~A} / \mathrm{T}$ & 1.000 & 0.559 & 1.000 & 1.000 \\
\hline 12533_73 & 07 & 21.4 & $\mathrm{G} / \mathrm{A}$ & 1.000 & 1.000 & 0.154 & 0.618 \\
\hline 13102_76 & 11 & 0.8 & $\mathrm{G} / \mathrm{A}$ & 1.000 & 1.000 & 0.400 & 0.588 \\
\hline 14353_126 & 12 & 12.6 & $\mathrm{G} / \mathrm{A}$ & 0.786 & 1.000 & 0.150 & 0.500 \\
\hline 14391_73 & 09 & 9.4 & $\mathrm{~A} / \mathrm{T}$ & 0.214 & 0.971 & 1.000 & 0.706 \\
\hline 14608_73 & 01 & 48.7 & $T / G$ & 1.000 & 1.000 & 0.175 & 0.588 \\
\hline 1473_122 & 09 & 6.1 & $\mathrm{G} / \mathrm{A}$ & 0.643 & 1.000 & 1.000 & 0.824 \\
\hline 14743_107 & 05 & 54.0 & $\mathrm{~T} / \mathrm{C}$ & 0.429 & 0.000 & 1.000 & 0.824 \\
\hline 15233_98 & 11 & 26.1 & $\mathrm{C} / \mathrm{G}$ & 1.000 & 1.000 & 0.263 & 0.588 \\
\hline 16018_58 & 07 & 10.9 & $\mathrm{~T} / \mathrm{C}$ & 1.000 & 0.441 & 0.150 & 0.618 \\
\hline 16460_134 & 04 & 18.7 & $\mathrm{~A} / \mathrm{T}$ & 1.000 & 1.000 & 0.564 & 0.824 \\
\hline 17159_26 & 02 & 37.7 & $A / G$ & 1.000 & 1.000 & 0.550 & 0.735 \\
\hline 177_149 & 08 & 44.3 & $\mathrm{C} / \mathrm{A}$ & 1.000 & 1.000 & 0.825 & 0.912 \\
\hline 18967_46 & 07 & 49.6 & $\mathrm{~T} / \mathrm{C}$ & 1.000 & 0.912 & 0.775 & 0.941 \\
\hline 2219_98 & 02 & 62.4 & $\mathrm{G} / \mathrm{A}$ & 1.000 & 1.000 & 0.788 & 0.882 \\
\hline 22561_111 & 02 & 76.3 & $\mathrm{G} / \mathrm{A}$ & 0.571 & 1.000 & 1.000 & 0.794 \\
\hline 23240_125 & 12 & 3.5 & $\mathrm{~A} / \mathrm{T}$ & 1.000 & 0.382 & 1.000 & 1.000 \\
\hline 24122_43 & 01 & 13.1 & $A / G$ & 0.214 & 0.912 & 1.000 & 0.559 \\
\hline 24959_44 & 06 & 14.9 & $\mathrm{C} / \mathrm{T}$ & 1.000 & 1.000 & 0.488 & 0.588 \\
\hline 262_54 & 05 & 13.4 & $\mathrm{C} / \mathrm{T}$ & 0.714 & 0.559 & 0.925 & 0.735 \\
\hline 26669_93 & 07 & 26.5 & $\mathrm{~A} / \mathrm{C}$ & 0.786 & 1.000 & 1.000 & 0.912 \\
\hline 26674_123 & 01 & 69.0 & $\mathrm{C} / \mathrm{T}$ & 1.000 & 1.000 & 0.638 & 0.912 \\
\hline 27408_32 & 08 & 32.6 & $\mathrm{C} / \mathrm{T}$ & 1.000 & 1.000 & 0.313 & 0.618 \\
\hline 28714_26 & 02 & 17.6 & $\mathrm{G} / \mathrm{A}$ & 1.000 & 0.735 & 1.000 & 1.000 \\
\hline 30876_169 & 07 & 29.8 & $\mathrm{~T} / \mathrm{C}$ & 0.286 & 1.000 & 1.000 & 0.588 \\
\hline 3239_136 & 04 & 26.7 & $A / G$ & 0.643 & 1.000 & 1.000 & 0.794 \\
\hline 3252_33 & 08 & 37.1 & $\mathrm{C} / \mathrm{T}$ & 0.643 & 1.000 & 1.000 & 0.706 \\
\hline 33254_153 & 04 & 31.4 & $\mathrm{C} / \mathrm{T}$ & 1.000 & 1.000 & 0.738 & 0.912 \\
\hline
\end{tabular}




\begin{tabular}{|c|c|c|c|c|c|c|c|}
\hline 36048_114 & 01 & 69.5 & $\mathrm{C} / \mathrm{T}$ & 1.000 & 1.000 & 0.250 & 0.618 \\
\hline 37241_49 & 10 & 13.9 & $\mathrm{~A} / \mathrm{T}$ & 0.643 & 1.000 & 1.000 & 0.824 \\
\hline 3876_115 & / & / & $\mathrm{T} / \mathrm{C}$ & 1.000 & 0.559 & 1.000 & 1.000 \\
\hline 38812_93 & 10 & 19.5 & $\mathrm{~A} / \mathrm{C}$ & 1.000 & 1.000 & 0.200 & 0.588 \\
\hline 39014_71 & 04 & 45.7 & $\mathrm{~A} / \mathrm{G}$ & 0.786 & 1.000 & 1.000 & 0.676 \\
\hline 4137_29571 & 07 & 19.4 & $\mathrm{C} / \mathrm{G}$ & 1.000 & 0.000 & 0.650 & 0.853 \\
\hline 4285_31 & 05 & 24.3 & $\mathrm{C} / \mathrm{G}$ & 1.000 & 1.000 & 0.538 & 0.882 \\
\hline 435_64 & 12 & 37.7 & $\mathrm{C} / \mathrm{G}$ & 1.000 & 1.000 & 0.775 & 0.941 \\
\hline 4856_83 & 12 & 15.6 & $\mathrm{C} / \mathrm{T}$ & 1.000 & 0.529 & 1.000 & 1.000 \\
\hline 6083_144 & 02 & 66.6 & $\mathrm{~A} / \mathrm{G}$ & 1.000 & 1.000 & 0.325 & 0.735 \\
\hline 6207_157 & 01 & 76.4 & $\mathrm{G} / \mathrm{C}$ & 0.786 & 1.000 & 1.000 & 0.706 \\
\hline 6505_48 & 01 & 73.9 & $\mathrm{~T} / \mathrm{A}$ & 0.500 & 1.000 & 1.000 & 0.676 \\
\hline 6519_41_95_2 & 04 & 40.6 & $\mathrm{G} / \mathrm{A}$ & 0.714 & 0.471 & 1.000 & 0.853 \\
\hline 6803_119 & 07 & 10.9 & $\mathrm{C} / \mathrm{T}$ & 0.857 & 0.441 & 1.000 & 0.647 \\
\hline 774_155 & 04 & 20.2 & $\mathrm{~A} / \mathrm{T}$ & 1.000 & 1.000 & 0.838 & 0.941 \\
\hline 8143_154 & 08 & 10.9 & $\mathrm{C} / \mathrm{G}$ & 0.571 & 1.000 & 1.000 & 0.824 \\
\hline 8363_141 & 07 & 9.7 & $\mathrm{G} / \mathrm{A}$ & 1.000 & 1.000 & 0.138 & 0.676 \\
\hline AC_32934_470 & 02 & 71.7 & $\mathrm{C} / \mathrm{T}$ & 0.429 & 0.824 & 0.950 & 0.529 \\
\hline AC_39247_1551 & 05 & 49.6 & $\mathrm{~T} / \mathrm{C}$ & 1.000 & 1.000 & 0.550 & 0.824 \\
\hline b1_SNP_higher_path_12837 & 02 & 52.8 & $\mathrm{G} / \mathrm{A}$ & 0.429 & 1.000 & 0.363 & 0.412 \\
\hline b1_SNP_higher_path_18882 & 02 & 21.2 & $\mathrm{~A} / \mathrm{C}$ & 1.000 & 1.000 & 0.438 & 0.706 \\
\hline b1_SNP_higher_path_5736 & 04 & 7.1 & $\mathrm{G} / \mathrm{A}$ & 0.929 & 0.853 & 0.625 & 0.706 \\
\hline CC_22194_867 & 12 & 41.6 & $\mathrm{G} / \mathrm{A}$ & 1.000 & 0.618 & 0.838 & 0.971 \\
\hline CC_23658_1308 & 11 & 42.8 & $\mathrm{G} / \mathrm{A}$ & 1.000 & 0.794 & 0.750 & 0.912 \\
\hline CC_34458_544 & 04 & 36.2 & $\mathrm{G} / \mathrm{A}$ & 1.000 & 0.529 & 0.738 & 0.941 \\
\hline CC_4168_418 & 01 & 39.3 & $\mathrm{C} / \mathrm{T}$ & 0.714 & 0.941 & 0.000 & 0.471 \\
\hline CC_45599_593 & 02 & 78.3 & $\mathrm{~T} / \mathrm{C}$ & 0.857 & 0.294 & 1.000 & 0.971 \\
\hline CC_46354_1005 & / & I & $\mathrm{C} / \mathrm{T}$ & 1.000 & 0.529 & 0.713 & 0.824 \\
\hline CC_47186_942 & 04 & 7.7 & $\mathrm{G} / \mathrm{A}$ & 1.000 & 0.147 & 0.625 & 0.941 \\
\hline SNP_10570_98_A_T & 07 & 31.8 & $\mathrm{~T} / \mathrm{A}$ & 0.500 & 0.000 & 0.863 & 0.735 \\
\hline SNP_11428_101_A_G & 05 & 27.6 & $\mathrm{G} / \mathrm{A}$ & 1.000 & 0.000 & 0.525 & 0.882 \\
\hline SNP_12453_74_G_A & 11 & 0.8 & $\mathrm{G} / \mathrm{A}$ & 1.000 & 1.000 & 0.400 & 0.588 \\
\hline
\end{tabular}




\begin{tabular}{|llllllll|} 
SNP_15209_73_A_G & 12 & 38.5 & A/G & 1.000 & 1.000 & 0.500 & 0.706 \\
\hline SNP_15252_70_A_G & 01 & 66.2 & A/G & 1.000 & 1.000 & 0.325 & 0.588 \\
\hline SNP_17902_74_C_T & 06 & 40.6 & C/T & 1.000 & 1.000 & 0.588 & 0.735 \\
\hline SNP_7453_81_A_T & 04 & 14.1 & A/T & 0.429 & 0.735 & 1.000 & 0.853 \\
\hline SNP_higher_path_9439722 & 06 & 5.3 & G/A & 1.000 & 1.000 & 0.650 & 0.794 \\
\hline
\end{tabular}

${ }^{1}$ Location on the 12 chromosomes of the reference genome of $C$. mollissima.

${ }^{2}$ The two alleles of each SNP are indicated and the frequency of the first allele (the most abundant in the overall sample) is provided for the three chestnuts species and for the $C$. sativa $\times$. crenata $(\mathrm{s} \times \mathrm{c}$ ) hybrids.

\section{Figures}
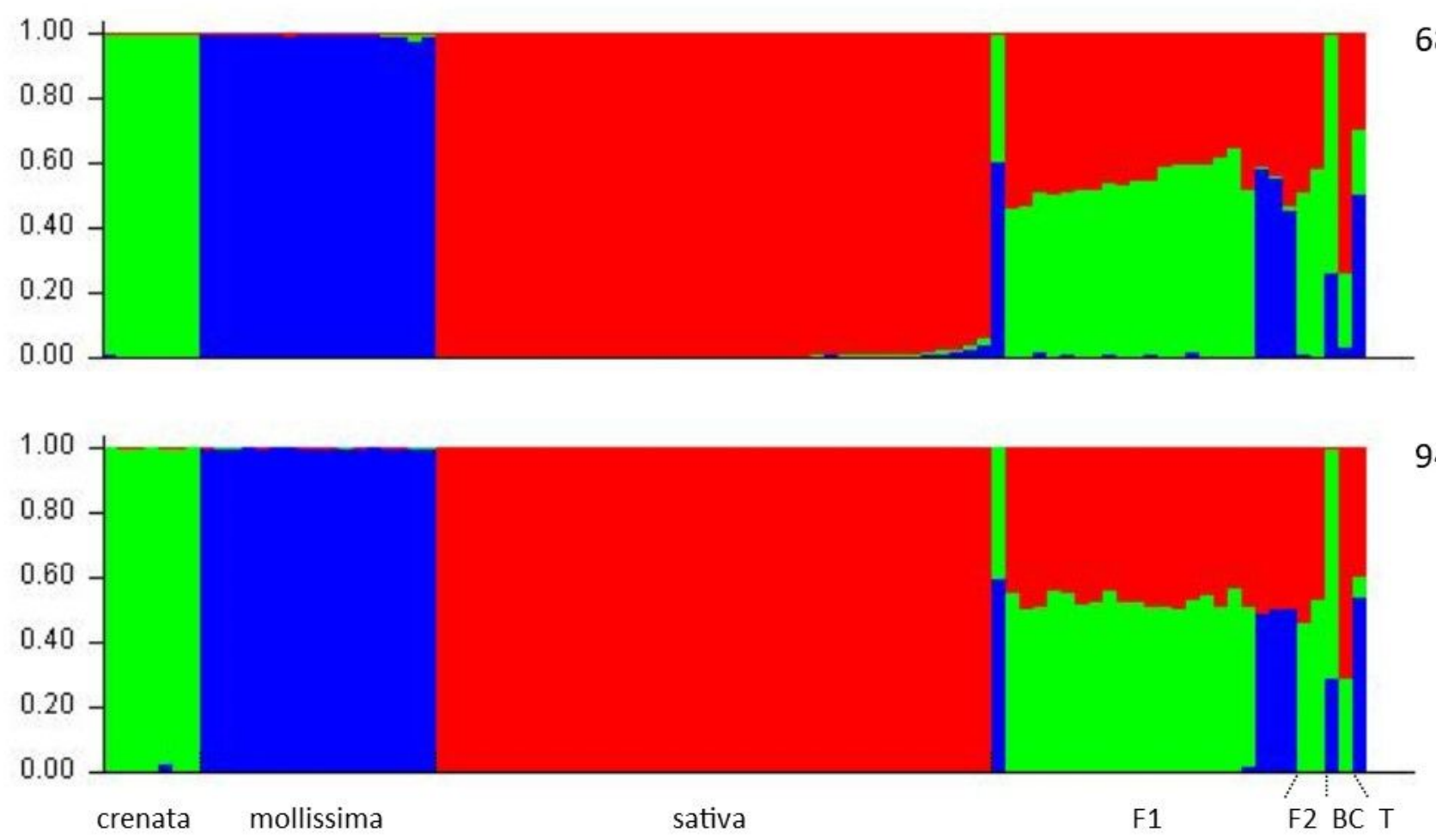

\section{Figure 1}

Comparison of species assignment for 91 chestnut trees characterized with 68 SNPs (top) and 94 SSRs (bottom). Results are very similar even though the admixture values of hybrids and other crosses are closer to the expected proportions with SSRs than with SNPs, except for the three-way hybrid (T). 